\title{
PENERAPAN PERFORMANCE ASSESSMENT UNTUK MENILAI KEMAMPUAN KOMUNIKASI MATEMATIKA SISWA PADA MATERI TURUNAN DI SMA NEGERI KOTA BANDA ACEH
}

\author{
Drs. M. Isa, M.Pd. ${ }^{1}$ \& Drs. Burhanuddin AG, M.Pd ${ }^{2}$ \\ Universitas Serambi Mekkah \\ Email: Isa_6467@yahoo.co.id
}

\begin{abstract}
Abstrak : Tujuan dalam penelitian ini adalah untuk menemukan Model Evaluasi Performance Assessment untuk menilai kemampuan komunikasi matematika siswa pada materi turunan di SMA Negeri Kota Banda Aceh, menerapkan model dan evaluasi performance assessment untuk menilai kemampuan komunikasi matematika siswa pada materi turunan di SMA Negeri Kota Banda Aceh dan untuk mengetahui bagaimana respon dan kemampuan siswa terhadap komunikasi matematika mereka baik secara tertulis maupun lisan. Metode yang digunakan dalam penelitian ini adalah penelitian pengembangan. Alat pengumpulan data yang digunakan adalah berupa performance assessment task dan angket respon kepada siswa. Berdasarkan hasil analisis data, diketahui bahwa pencapaian kemampuan komunikasi matematika siswa di SMAN Kota Banda Aceh secara tertulis dan lisan melalui penerapan performance assesment umumnya berada dalam kategori baik dan dari analisis angket ditemukan respon siswa mengenai komponen pembelajaran lebih dari setengah persen. Kesenangan mereka terhadap komponen pembelajaran tersebut juga menunjukkan respon postif.
\end{abstract}

Kata kunci: Performance assessment dan Komunikasi Matematika

Abstract: the purpose of this research was to find out the evaluation model of performance assessment to assessed student's mathematic communication skill in Derivative Matter in SMA Negeri Kota Banda Aceh, applied the model and evaluation of performance assessment to assessed student's mathematic communication skill in Derivative Matter in SMA Negeri Kota Banda Aceh, and to know how student's responses and mathematic communication skill is in both written and verbal. The

${ }^{1}$ Drs. M. Isa, M.Pd.

${ }^{2}$ Drs. Burhanuddin AG, M.Pd adalah dosen serambi Mekah Aceh 
study was adopted as a research and development. The performance assessment task and students' responses questionnaire was used to collect the data. Based on the data analyses result, showed that achievement of student's mathematic communication skill in SMA Negeri Kota Banda Aceh in both written and verbal using performance assessment generally placed in good cathegory and from analyses of responses questionnaire, it is known that student's responses about learning component more than half a percent. Their attract to the learning component also showed positive responses.

\section{PENDAHULUAN}

Keberhasilan proses pembelajaran dapat diketahui melalui penilaian, dapat di gunakan untuk mengetahui sejauh mana siswa memahami materi dan sejauh mana tujuan pembelajaran telah tercapai. Sesuai dengan pendapat Oakland Community College (2008) menyatakan penilaian bertujuan untuk mengamati dan meningkatkan pembelajaran siswa. Melalui penilaian hasil pencapaian siswa, efektivitas proses dapat diukur apakah diperlukan perbaikan atau tidak. Selain itu, penilaian juga dapat memberikan feedback tidak hanya untuk proses pembelajaran tetapi juga siswa maupun guru sehingga dapat memperbaiki dan meningkatkan hasil pembelajaran. Jadi, tidak hanya menjadi bagian dari proses pembelajaran, penilaian juga sangat memegang peranan penting di dalamnya.

Perlu diperhatikan bahwa penilaian itu tidak hanya sekedar melihat hasil akhir melainkan proses. Sejalan dengan pengertian yang dikembangkan oleh Oakland Community College (2008) bahwa penilaian merupakan suatu proses yang berkelanjutan. Hal ini dikuatkan oleh Airasian (2005:9) yang menyatakan bahwa penilaian sebagai suatu proses yang luas, meliputi proses pengumpulan, sintesis dan interpretasi suatu informasi yang juga melibatkan tes, perhitungan dan evaluasi. Jadi, penilaian merupakan suatu proses yang terdiri dari sederetan aktivitas menilai selama proses pembelajaran berlangsung.

Salah satu bentuk penilaian yang dapat diterapkan untuk menilai proses pembelajaran siswa adalah authentic assessment. Authentic assessment ini berbeda dengan traditional assessment yang hanya berupa pencil and paper test, menjawab satu pilihan jawaban dan hanya fokus kepada hasil akhir. Authentic assessment tidak berfokus kepada satu jawaban tunggal namun lebih kepada bagaimana dan mengapa siswa menjawab suatu persoalan (Mustamin, 
2010:34). Penilaian ini didesain untuk mengembangkan integration of factual knowledge (written and performance), membangun pemikiran yang berbeda dalam menghasilkan jawaban, mengembangkan meaningful skills melalui real world tasks, memprioritaskan proses dan membangun kerjasama di kalangan siswa (Mandernach, 2003). Oleh sebab itulah Kementerian Pendidikan dan Kebudayaan (2013:10) menuntut guru untuk menerapkan penilaian autentik dalam proses pembelajaran, keunggulan penilaian autentik ini adalah menilai dan melihat sejauh mana kemampuan komunikasi siswa yang tidak cukup dinilai melalui traditional assessment. Beberapa guru seringkali mengesampingkan komunikasi matematika dan lebih menitikberatkan kepada aspek komputasi dan kalkulasi saja sedangkan di dalam pembelajaran matematika, komunikasi merupakan bagian penting guna menyampaikan simbol-simbol dan ide-ide matematika agar dapat dipahami oleh orang lain. Sama halnya dengan ungkapan Sumarmo (2006:2) bahwa matematika sebagai bahasa simbol bersifat universal dan dapat dipahami oleh setiap orang, kapan dan dimana saja. Selain itu, komunikasi matematika merupakan salah satu persyaratan dalam standar proses pembelajaran matematika yang ditetapkan oleh National Council of Teachers of Mathematics (NCTM) yang secara rinci disebutkan bahwa siswa diharapkan mampu: (a) Menyusun dan mengaitkan mathematical thinking mereka melalui komunikasi. (b) Mengkomunikasikan mathematical thinking mereka secara logis dan jelas kepada teman-temannya, guru, dan orang lain. (c) Menganalisis dan menilai mathematical thinking dan strategi yang dipakai orang lain. (d) Menggunakan bahasa matematika untuk mengekspresikan ide-ide matematika secara benar. (CSSU Curriculum Frameworks, 2004:21)

Hal tersebut juga sesuai dengan tujuan pembelajaran matematika sebagaimana tercantum dalam Peraturan Menteri Pendidikan Nasional Nomor 22 Tahun 2006 tentang standar kompetensi kelulusan dalam bidang matematika (dalam Mahmudi, 2009:1) yaitu "melalui pembelajaran matematika siswa diharapkan mengkomunikasikan gagasan dengan simbol, tabel atau media lain untuk memperjelas keadaan atau masalah." Kementerian Pendidikan dan Kebudayaan (2013:10) juga menegaskan dalam "Pembelajaran Berbasis Kompetensi Mata Pelajaran Matematika" bahwa penguatan proses pembelajaran dilakukan melalui pembelajaran yang mendorong siswa lebih mampu dalam mengamati, menanya, mengumpulkan data, mengasosiasi/menalar, dan mengkomunikasikan. Selain sebagai komponen dalam pembelajaran matematika, komunikasi matematika merupakan syarat 
untuk memecahkan masalah, artinya jika siswa tidak dapat berkomunikasi dengan baik memaknai permasalahan maupun konsep matematika maka ia tidak dapat menyelesaikan masalah tersebut dengan baik (Hulukati dalam Qohar, 2009:M-339). Oleh karena itu, diharapkan bagi guru agar dapat menerapkan authentic assessment guna melihat, menilai dan mengembangkan kemampuan komunikasi matematika siswa.

Namun, pada kenyataannya beberapa guru lebih sering menggunakan traditional assessment dibandingkan authentic assessment dalam pembelajaran matematika sehingga aspek komputasi lebih dominan dalam penilaian, sementara aspek komunikasi kurang menjadi sorotan guru. Alhasil, kemampuan komunikasi yang kurang dikembangkan menyebabkan siswa sulit dalam menyampaikan ide-ide matematikanya sehingga sulit juga dalam menyelesaikan suatu permasalahan matematika. Berdasarkan studi Rohaeti pada tahun 2003, rata-rata kemampuan komunikasi matematis siswa berada dalam kualifikasi kurang (Fachrurazi, 2011:78). Hajjina (2013:4) juga mengatakan bahwa kemampuan komunikasi matematis siswa dalam memecahkan masalah matematika masih cukup rendah. Mereka cenderung menjawab soal secara langsung tanpa melalui tahap-tahapan yang seharusnya dikerjakan terutama pada soal cerita. Hal ini dikerenakan guru sering menggunakan traditional assessment dimana lebih mengedepankan hasil daripada proses sehingga mengakibatkan komunikasi matematika siswa tidak terbangun dan akhirnya berujung kepada hasil belajar yang rendah.

Salah satu cara untuk menilai dan membangun komunikasi matematika siswa adalah dengan menerapkan salah satu bentuk penilaian autentik yaitu performance assessment. Performance assessment adalah salah satu pilihan yang tepat sebab penilaian ini memberikan siswa tugas yang memuat aspek komunikasi matematika dan memberikan kesempatan kepada siswa untuk mengeksplor berbagai kemungkinan alasan dan jawaban (Sumarmo, 2006:15). Lebih lanjut, menurut Rudner \& Boston serta Wiggins (dalam Houghton Mifflin University, 1997), performance assessment memberikan kesempatan kepada siswa untuk mendemonstrasikan pengetahuan, skil dan strategi dengan membuat respon atau produk. Penilaian ini berguna untuk mengamati bagaimana pemahaman siswa terhadap konsep yang telah diajarkan dan bagaimana kemampuan mereka untuk mengaplikasikan procedural knowledge and skill mereka (Airasian, 2005:235; Suskie, 2009:26). Performance assessment lebih menekankan pada persoalan nyata yang berkaitan dengan kehidupan sehari-hari (Airasian, 2005:234). Lane (2010:3) juga sependapat 
bahwa performance assessment lebih fokus kepada menyelesaikan permasalahan yang realistis dan bermakna. Kemudian, berdasarkan penelitian yang dilakukan oleh Idha (2008:69) menunjukkan bahwa pembelajaran melalui performance assessment dapat meningkatkan pemahaman konsep mata pelajaran biologi dan juga motivasi siswa. Jadi, performance assessment dengan tugas yang berkaitan dengan kehidupan nyata cocok diterapkan untuk menilai dan mengembangkan komunikasi matemata siswa.

Oleh karena itu model penilaian performance assessment merupakan solusi yang dapat ditempuh dalam meningkatkan hasil belajar matematika dan membentuk karakter siswa melalui nilai-nilai pendidikan matematika yaitu dengan menemukan model performance assessment untuk menilai kemampuan komunikasi matematika siswa pada materi turunan di SMA Negeri Kota Banda Aceh.

Tujuan khusus dari penelitian ini adalah sebagai berikut: (1) Menemukan Model Evaluasi Performance Assessment untuk menilai kemampuan komunikasi matematika siswa pada materi turunan di SMA Negeri Kota Banda Aceh. (2) Penerapan model dan evaluasi performance assessment untuk menilai kemampuan komunikasi matematika siswa pada materi turunan di SMA Negeri Kota Banda Aceh. (3) Untuk mengetahui bagaimana respon siswa terhadap komunikasi matematika mereka baik secara tertulis maupun lisan melalui penerapan performance assessment pada materi turunan di SMA Negeri Kota Banda Aceh. (4) Untuk mengetahui bagaimana kemampuan komunikasi matematika siswa secara tertulis dan lisan melalui penerapan performance assessment pada materi turunan bagi siswa di SMA Negeri Kota Banda Aceh.

\section{LANDASAN TEORI}

Pembelajaran adalah suatu kegiatan dimana terjadinya proses penguasaan pengetahuan, keterampilan dan perubahan sikap oleh subjek yang sedang belajar. Peserta didik sebagai subjek yang sedang belajar perlu dilibatkan secara aktif sesuai dengan pernyataan dari Kementerian Pendidikan dan Kebudayaan (2013:7) bahwa prinsip pembelajaran lebih menekankan pada pengembangan kreativitas peserta didik (tut wuri handayani). Begitu pula halnya dengan pembelajaran matematika, siswa harus aktif dalam mengembangkan kreativitasnya.

Pembelajaran matematika mengacu pada prinsip "learning how to learn" yang rinciannya termuat dalam empat pilar pendidikan yaitu: (1) 
learning to know, (2) learndo, (3) learning to be, dan (4) learning to live together (Sumarmo, 2006:2). Dalam hal ini, siswa mencari sendiri makna dari pembelajarannya dan guru hanya sebagai organisator dan fasilitator sebab pembelajaran berbasis keterampilan lebih menekankan pada kemampuan peserta didik dalam menemukan sendiri pengetahuan yang didasarkan atas pengalaman belajar, hukum-hukum, prinsi-prinsip dan generalisasi sehingga lebih memberikan kesempatan bagi berkembangnya keterampiran berpikir tingkat tinggi (Kementerian Pendidikan dan Kebudayaan, 2013:8). Apalagi dalam pembelajaran matematika, dimana peserta didik harus benar-benar memahami konsep dengan baik dan kemampuan mereka dalam menemukan konsep dari pembelajaran sangat diharapkan.

Sumarmo (2006:3) mengemukakan beberapa kemampuan dasar dan sikap yang harus dimiliki siswa dalam pembelajaran matematika sebagai berikut.

Secara garis besar, kemampuan dasar matematika tersebut dapat diklasifikasikan dalam lima standar yaitu kemampuan: (1) mengenal, memahami dan menerapkan konsep, prosedur, prinsip dan idea matematika, (2) menyelesaikan masalah matematik (mathematical problem solving), (3) bernalar matematik (mathematical reasoning), (4) melakukan koneksi matematik (mathematical connection), dan (5) komunikasi matematik (mathematical communication). Adapun sikap yang harus dimiliki siswa di antaranya adalah sikap kritis dan cermat, obyektif dan terbuka, menghargai keindahan matematika, serta rasa ingin tahu dan senang belajar matematika. Sikap dan kebiasaan berfikir seperti di atas pada hakekatnya akan membentuk dan menumbuhkan disposisi matematik (mathematical disposition) yaitu keinginan, kesadaran dan dedikasi yang kuat pada diri siswa untuk belajar matematika dan melaksanakan berbagai kegiatan matematika.

Moesono (dalam Sumarmo, 2006:7-8) juga menyatakan bahwa "pembelajaran matematika hendaknya sebagai alat untuk mengembangkan kemampuan pemecahan masalah matematik, berpikir kritis, dan berkomunikasi atau berekspresi secara kreatif." Berdasarkan beberapa pendapat di atas dapat disimpulkan bahwa dalam pembelajaran siswa dituntut aktif dan kreatif, khususnya dalam pembelajaran matematika dimana siswa diharapkan memiliki kemampuan dalam memahami konsep, memecahkan masalah, berpikir kritis, koneksi matematika dan komunikasi matematika. 
Komunikasi sangat penting dalam pembelajaran sebab komunikasi adalah sarana untuk menyampaikan hasil konseptualisasi dalam bentuk lisan, tulisan, gambar/sketsa, diagram atau grafik. Ini diperlukan agar siswa mampu mengomunikasikan pengetahuan, keterampilan dan penerapannya serta kreasi siswa melalui presentasi, membuat laporan dan/atau unjuk karya (Kementerian Pendidikan dan Kebudayaan, 2013:13). Demikian pula halnya dalam pembelajaran matematika, komunikasi merupakan esensi dari mengajar, assessing dan belajar matematika (Umar, 2012:2) sebab menurut Depka (dalam Agustyaningrum, 2010:26), "Komunikasi adalah cara untuk menyalurkan ideide dan merefleksikan pemahaman tentang matematika."

Komunikasi matematika adalah suatu cara untuk mengungkapkan ideide matematika baik secara lisan, tertulis, gambar, diagram, menggunakan benda, menyajikan dalam bentuk aljabar atau menggunakan simbol matematika (NCTM, 2000:60). Departemen Pendidikan Nasional (dalam Putri, 2011:551) juga menyebutkan bahwa komunikasi matematis merupakan kesanggupan/kecakapan siswa untuk menyatakan dan menafsirkan gagasan matematis secara lisan, tertulis atau mendemonstrasikan apa yang ada dalam persoalan matematika. Ada beberapa indikator komunikasi matematika yang dikemukakan oleh Sumarmo (2006:3), yaitu:

- Menjelaskan idea, situasi dan relasi matematik, secara lisan atau tulisan, dengan benda nyata, gambar, grafik dan aljabar.

- Menyatakan peristiwa sehari-hari dalam bahasa atau simbol matematika.

- Mendengarkan, berdiskusi, dan menulis tentang matematika.

- Membaca presentasi matematika tertulis dan menyusun pertanyaan yang relevan.

- Membuat konjektur, menyusun argumen, merumuskan definisi dan generalisasi.

Penilaian autentik merupakan penilaian yang dilakukan secara komprehensif untuk menilai mulai dari masukan (input), proses, dan keluaran (output). Penilaian ini menilai kesiapan siswa serta proses dan hasil belajar yang utuh (Kementerian Pendidikan dan Kebudayaan, 2013:10). Salah satu bentuk penilaian autentik adalah performance assessment. Performance assessment mengukur kemampuan siswa dalam mendemonstrasikan skill yang relevan dalam konteks autentik sehingga termasuk ke dalam penilaian autentik.

Ada beberapa hal mengapa performance assessment lebih dianjurkan untuk digunakan. Performance assessment lebih menekankan pada real-world 
problem solving (Airasian, 2005:234). Ketika siswa diberikan kesempatan untuk belajar bermakna dengan tugas-tugas yang berhubungan dengan kehidupan nyata, mereka dikatakan telah menunjukkan performance yang meningkat (Lane, 2010:60). Lane (2010:4) juga mengatakan bahwa performance assessment menuntut siswa untuk menkonstruk sebuah original product atau respon seperti menulis sebuah penjelasan dari suatu penyelesaian. Jadi, penilaian ini merupakan bentuk penilaian hasil belajar yang berorientasi pada proses (Kementerian Pendidikan dan Kebudayaan, 2013:16) sehingga penilaian menjadi lebih relevan sebab siswa terlibat langsung di dalam penilaian tersebut (Edutopia, 2008).

Selain itu, performance assessment juga berguna untuk mengukur kemampuan siswa dalam mengaplikasikan procedural knowledge (Suskie, 2009:26), menerjemahkan pengetahuan dan pemahaman ke dalam aksi (Airasian, 2005:234-235), mendemonstrasikan skill yang penting (Arends, 2004:245), mengevaluasi acquisition of knowledge, konsep dan skill (Wren, 2009:1), serta mengembangkan content-specific skill (Mandernach, 2003). Palm (2008:3) menambahkan performance assessment memiliki kemungkinan lebih baik dalam menilai skil yang kompleks dan komunikasi siswa. Intinya, performance assessment ini bertujuan agar guru dapat melihat bagaimana siswa merencanakan pemecahan masalah, melihat dan mengamati bagaimana siswa menunjukkan pengetahuan dan keterampilannya (Kementerian Pendidikan dan Kebudayaan, 2013:16).

Ada beberapa keuntungan menerapkan performance assessment secara formal, antara lain:

1. menunjukkan bagaimana siswa menggunakan pengetahuan untuk melakukan kegiatan dan menghasilkan sesuatu;

2. instrumen penilaian dapat digunakan berkali-kali;

3. instrument penilaian dapat digunakan untuk tujuan diagnostik;

4. dengan instrumen yang sama, guru dapat membuat grafik perkembangan siswa dari waktu ke waktu;

5. memungkinkan siswa berkompetisi dengan dirinya sendiri;

6. bukan akhir, tetapi bagian dari proses pembelajaran; dan

7. membuat pelajaran di sekolah menjadi relevan dengan dunia nyata.

(Kementerian Pendidikan dan Kebudayaan, 2013:16)

Jadi, penerapan performance assessment dalam pembelajaran tidak hanya membantu guru menilai siswa tetapi juga dapat digunakan sebagai tujuan diagnostik, melihat perkembangan siswa selama proses pembelajaran 
dan yang paling penting membuat pembelajaran lebih bermakna dengan mengaitkan pembelajaran ke dalam kehidupan nyata serta mengembangkan komunikasi siswa.

\section{METODE}

Jenis penelitian yang digunakan dalam penelitian ini adalah penelitian kuantitatif deskriptif karena penelitian ini bertujuan melihat dan menggambarkan kemampuan komunikasi siswa menyampaikan gagasan dalam memecahkan permasalahan matematika yang berhubungan dengan real world problem. Sejalan dengan pendapat Bungin (2009:48-49) yang menyatakan bahwa penelitian kuantitatif deskriptif dimaksudkan untuk menggambarkan dan menjelaskan berbagai kondisi atau situasi menurut kejadian sebagaimana adanya yang dapat diamati.

Selain itu Metodologi lain yang dipilih untuk penelitian ini adalah penelitian dan pengembangan (Research and Development) dikombinasikan dengan Metode Eksperimen dan kemudian diikuti dengan the one group pre test post test design (Suharsimi, 2006;86) di tahap keempat Research and Development.

Metode Research and Development merupakan pilihan karena memiliki proses yang lebih kompleks dalam tahap-tahapan yang dapat mengakomodasi beragam kepentingan penelitian ini (Borg \& Gall, 1989;785) Model Penilaian pembelajaran yang dikembangkan merupakan produk pengajaran terkait dengan teknologi instruksional yang membutuhkan justifikasi dalam proses pembelajaran. Konsekuensinya peneliti membutuhkan waktu yang panjang untuk membaca banyak buku dan teori, melakukan kunjungan dan melakukan focus group discussion ke berbagai pihak dan masuk ke dalam kelas untuk mengajar agar dapat merasakan dan menemukan berbagai fakta dan kondisi kekinian pembelajaran di SMA Metode R\&D membutuhkan proses dan menuntut semangat yang kuat, ketekunan, pengamatan yang dalam dan kritis, serta kesabaran panjang dalam memancing keluarya berbagai gagasan kreatif.

Kemudian memasukan metode action research di tahap ke lima Research and Development merupakan justifikasi untuk melihat sejauh mana model Penilaian pembelajaran ini berproses secara patut, efektif dan signifikan bagi anak di SMA. 


\begin{tabular}{|l|l|}
\hline \multicolumn{1}{|c|}{ Langkah Utama Borg and Gall } & \multicolumn{1}{c|}{ 10 Langkah Borg \& Gall } \\
\hline Research \& Information Collecting & Penelitian dan Pengumpulan informasi \\
\hline Planning form of & Perencanaan \\
\hline $\begin{array}{l}\text { Develop Preliminary fongembangan Product wal } \\
\text { Product. }\end{array}$ & \\
\hline \multirow{3}{*}{ Field testing \& Product Revision } & Uji Lapangan awal (Preliminary) \\
\cline { 2 - 2 } & Revisi Produk \\
\cline { 2 - 2 } & Uji Lapangan Utama (main) \\
\cline { 2 - 2 } & Revisi Produk Operasional \\
\cline { 2 - 2 } & Uji Lapangan Akhir \\
\hline Final Product Revision & Revisi Produk Akhir \\
\hline Dissemination \& Implementation & Diseminasi dan Implementasi \\
\hline
\end{tabular}

Data yang diperlukan untuk penelitian ini dikumpulkan melalui memberikan performance assessment task dan angket respon kepada siswa.

Pemberian performance assessment task dilakukan untuk menjawab pertanyaan penelitian yang pertama yaitu bagaimana kemampuan komunikasi matematika siswa dengan menerapkan performance assessment. Performance assessment task yang diberikan terdiri dari tiga macam, yaitu:

\section{a. Paper}

Tugas paper yang diberikan adalah membuat paper tentang aplikasi turunan dalam kehidupan nyata beserta real world problem-nya. Tugas ini diberikan waktu selama seminggu. Pemberian tugas ini bertujuan untuk mengetahui kemampuan komunikasi matematika secara tertulis dalam hal kemampuan siswa menyatakan relasi matematika dengan kehidupan nyata, menyatakan ide atau situasi dengan gambar dan aljabar serta memodelkan permasalahan matematika. Tugas ini akan dinilai dengan menggunakan rubrik penilaian paper.

\section{b. Presentasi}

Tugas presentasi diberikan setelah siswa membuat paper tentang aplikasi turunan. Pada tugas ini siswa diminta mempresentasikan hasil karya mereka di depan kelas. Pemberian tugas ini bertujuan untuk mengetahui kemampuan komunikasi matematika secara lisan dalam hal kemampuan siswa menyatakan relasi matematika dengan kehidupan nyata, menyatakan ide atau situasi dengan gambar, menginterpretasikan ide-ide matematika serta kemampuan berdiskusi dan presentasi tentang matematika. Tugas ini akan dinilai dengan menggunakan lembar pengamatan berupa rubrik presentasi. 


\section{c. Tes Tertulis}

Tes tertulis dilaksanakan pada pertemuan terakhir penelitian. Soal tes yang diberikan berbentuk essay sebanyak 4 soal yang umumnya terdiri dari real world problem. Tes dilakukan di ruangan kelas dan waktu yang diberikan 2 jam pelajaran, $2 \times 40$ menit yaitu 80 menit. Tes ini bertujuan untuk mengetahui kemampuan komunikasi matematika siswa secara tertulis dalam hal menyatakan ide atau situasi dengan gambar dan aljabar, menginterpretasikan ide-ide matematika dan memodelkan permasalahan matematika. Tes ini akan dinilai dengan menggunakan rubrik penilaian tes.

\section{d. Angket Respon Siswa}

Angket respon siswa disebarkan setelah proses pembelajaran dilaksanakan. Sebelum disebarkan, angket terlebih dahulu divalidasi dan selanjutnya validasi data akan dilakukan setelah angket terkumpulkan. Penyebaran angket kepada siswa bertujuan untuk menjawab pertanyaan penelitian yang kedua yaitu mengenai respon siswa terhadap komunikasi matematika mereka melalui penerapan performance assessment.

Setelah didapatkan nilai dari paper, presentasi dan tes tertulis, yang akan dilakukan selanjutnya menentukan kriteria nilai berdasarkan ketentuan penilaian kurikulum 2013 yang diterapkan di SMA Negeri Kota Banda Aceh. Nilai yang diperoleh dari perhitungan rubrik akan dikonversikan dan kemudian akan ditentukan predikatnya berdasarkan tabel berikut ini

Tabel 1 Konversi Nilai dan Predikat Pencapaian Siswa

\begin{tabular}{|c|c|c|c|}
\hline Interval & Hasil Konversi & Predikat & Kategori \\
\hline $96-100$ & 4.00 & $\mathrm{~A}$ & \multirow{2}{*}{ Sangat Baik } \\
\hline $91-95$ & 3.66 & A- & \\
\hline $85-90$ & 3.33 & $\mathrm{~B}+$ & \multirow{3}{*}{ Baik } \\
\hline $80-84$ & 3.00 & B & \\
\hline $75-79$ & 2.66 & B- & \\
\hline $70-74$ & 2.33 & $\mathrm{C}+$ & \multirow{3}{*}{ Cukup } \\
\hline $65-69$ & 2.00 & $\mathrm{C}$ & \\
\hline $60-64$ & 1.66 & C- & \\
\hline $55-59$ & 1.33 & $\mathrm{D}+$ & \multirow{2}{*}{ Kurang } \\
\hline$\leq 54$ & 1.00 & $\mathrm{D}$ & \\
\hline
\end{tabular}

(Sumber: Kementerian Pendidikan dan Kebudayaan, 2013)

\section{HASIL}

Berdasarkan hasil analisis data, diketahui bahwa pencapaian kemampuan komunikasi matematika siswa di SMAN Kota Banda Aceh secara 
tertulis dan lisan melalui penerapan performance assesment umumnya berada dalam kategori baik. Hal ini menjawab rumusan masalah pertama pada penelitian ini mengenai kemampuan komunikasi matematika secara tertulis dan lisan. Ini terbukti penerapan performance assessment task dapat menilai serta mengembangkan kemampuan komunikasi matematika siswa.

Dalam penerapan performance assessment ini, ada tiga tugas yang digunakan untuk menilai kemampuan komunikasi matematika siswa, di antaranya paper, presentasi dan tes tertulis. Tugas paper dan tes tertulis digunakan untuk menilai kemampuan komunikasi tertulis dan presentasi digunakan untuk menilai kemampuan komunikasi lisan dimana setiap tugas memiliki kriteria penilaian kemampuan komunikasi matematika. Hasil penelitian menunjukkan bahwa kemampuan komunikasi matematika siswa melalui ketiga tugas tersebut umumnya baik.
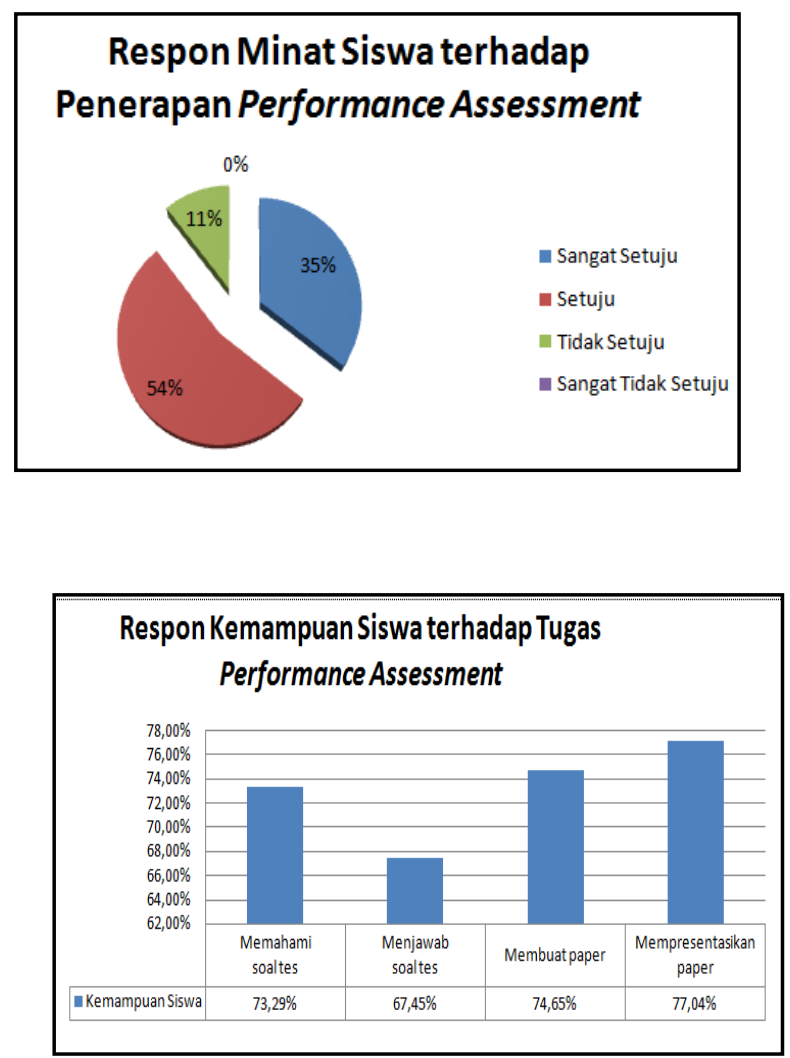

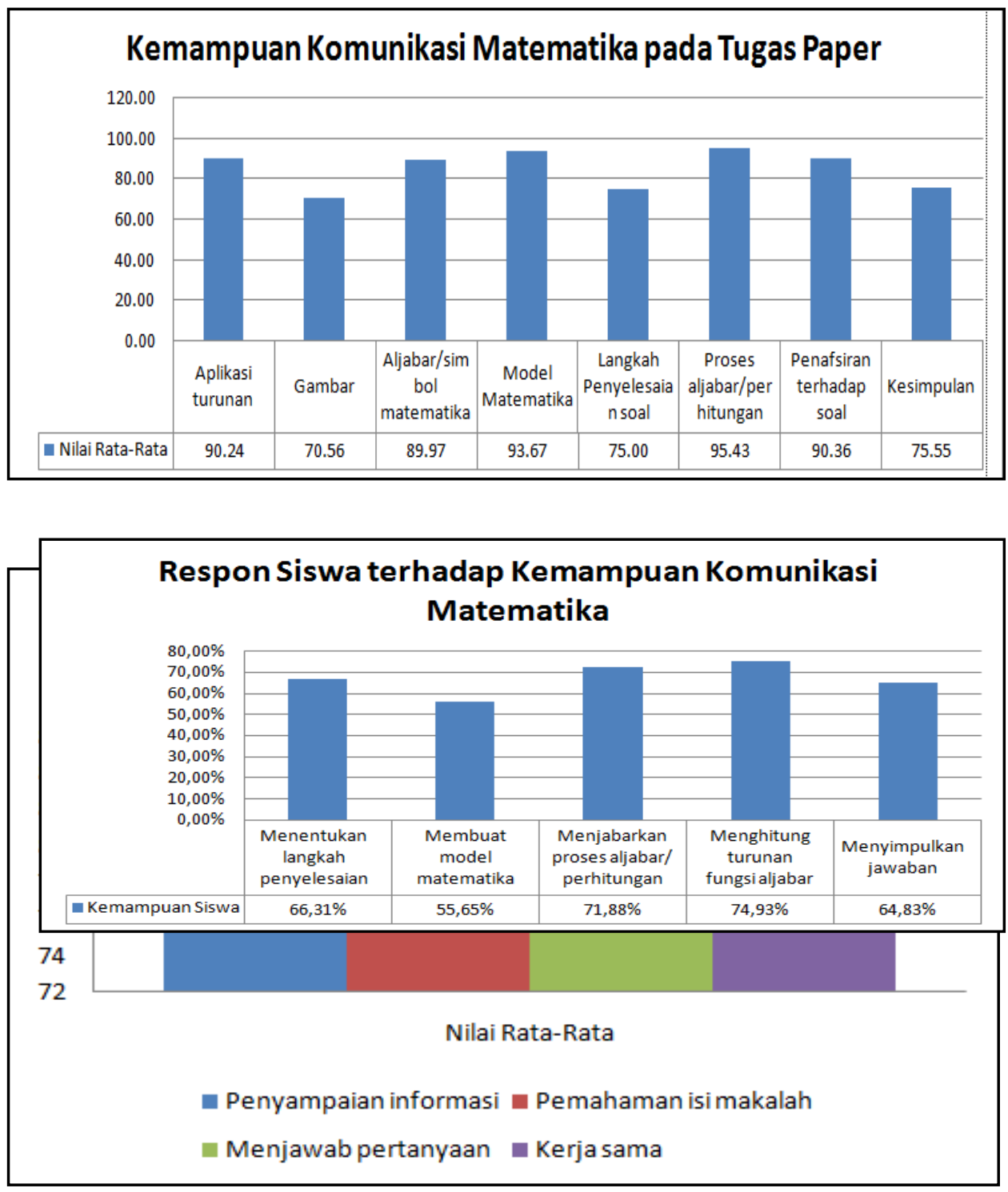


\section{Rata-rata Kemampuan Komunikasi Matematika pada Tes Tertulis}

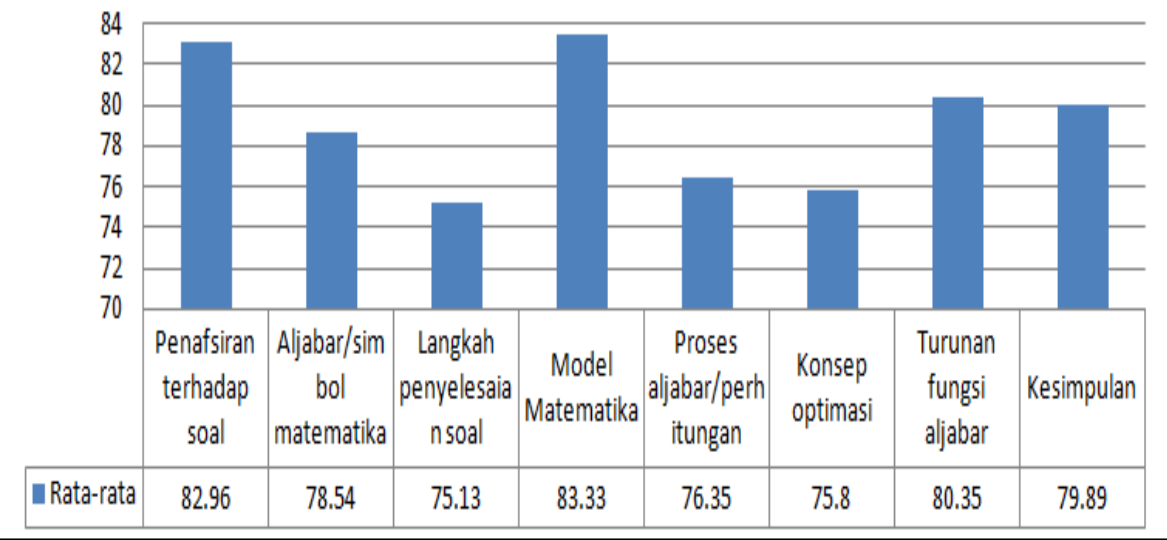

Untuk melihat kemampuan komunikasi matematika siswa secara tertulis, ada delapan kriteria yang menjadi acuan penilaian, baik pada paper maupun tes tertulis. Namun, diantara delapan kriteria tersebut, ada enam kriteria yang sama dan ada dua kriteria yang berbeda antara tugas paper dan tes tertulis. Analisis terhadap enam kriteria yang sama, menunjukkan kemampuan siswa dalam proses aljabar dan perhitungan melalui tugas paper dan tes tertulis memperoleh nilai rata-rata tertinggi, yaitu kategori sangat baik pada tugas paper dan kategori baik pada tes tertulis sedangkan kemampuan menyatakan kesimpulan dari jawaban yang diperoleh memiliki rataan terendah pada tes tertulis yaitu berada dalam kategori cukup. Sementara pada tugas paper, kemampuan menyatakan kesimpulan memperoleh rata-rata pada kategori baik. Kemampuan menentukan langkah penyelesaian soal, rataan yang diperoleh pada tugas paper tidak jauh berbeda pada tes tertulis. Meskipun demikian, kategori yang diperoleh terkesan sangat berbeda, yaitu kategori baik pada tugas paper dan cukup pada tes tertulis. Sementara kemampuan siswa pada kriteria model matematika, penafsiran soal dan penggunaan aljabar/simbol matematika sudah menunjukkan hasil yang memuaskan, yaitu berada dalam kategori sangat baik pada tugas paper dan kategori baik pada tes tertulis. 
Analisis terhadap dua kriteria yang berbeda, yaitu kriteria aplikasi turunan dan gambar pada tugas paper. Kemampuan siswa dalam menyatakan aplikasi turunan menunjukkan hasil pada kategori sangat baik sedangkan kemampuan menyatakan ide/situasi dengan gambar memiliki rataan yang masih terbilang rendah, yaitu berada dalam kategori cukup. Dua kriteria yang tidak terdapat pada tugas paper adalah turunan fungsi aljabar dan konsep optimasi. Pencapaian siswa terhadap kedua kriteria ini tergolong dalam kategori baik. Dari paparan di atas, tingginya kemampuan siswa dalam proses aljabar/perhitungan dikarenakan akibat dari pembelajaran di sekolah yang biasanya lebih ditekankan pada aspek perhitungan. Seperti yang diungkapkan Mahmudi (2009:1), "selama ini umumnya pembelajaran matematika lebih difokuskan pada aspek komputasi sehingga tidak heran jika perhitungan matematika siswa baik." Didukung pula oleh hasil studi Hamidah (2013:51) yang menyatakan $80,8 \%$ siswa tepat dalam perhitungan. Hal ini juga sesuai dengan respon siswa, bahwa mereka merasa lebih dari 50\% mampu dan mudah dalam menjabarkan proses aljabar dan perhitungan.

Rendahnya kemampuan siswa dalam menyatakan kesimpulan melalui tes tertulis bisa saja terjadi karena siswa tidak terbiasa menyimpulkan jawaban di akhir penyelesaian soal. Beberapa siswa benar dalam perhitungan tetapi salah dalam menyimpulkan. Rasiman (2013:190) juga menemukan hal serupa pada studinya bahwa siswa belum mampu mengambil kesimpulan yang tepat. Sesuai dengan respon siswa yang menyatakan bahwa tingkat kemampuan dan kemudahan mereka dalam menyimpulkan jawaban lebih rendah dibandingkan respon terhadap kemampuan perhitungan.

Terkait dengan langkah penyelesaian soal, diperoleh kategori cukup pada tes tertulis dikarenakan siswa melakukan banyak kesalahan dalam langkah penyelesaian soal pada soal nomor empat. Kebanyakan dari mereka tidak lengkap dalam menuliskan langkah penyelesaian soal. Hal ini diduga siswa terbiasa menggunakan cara cepat atau shortcut dalam menyelesaikan suatu persoalan yang umumnya digunakan pada tes akhir sekolah atau ujian nasional yaitu soal berupa pilihan ganda. Penelitian yang dilakukan oleh Rasiman (2013:190) juga menemukan bahwa siswa belum mengungkapkan secara lengkap langkah penyelesaian suatu masalah. Selain itu, faktor kesulitan soal nomor empat juga diduga mempengaruhi rendahnya kriteria langkah penyelesaian soal. Sama seperti penelitian Sulastri (2013:56) yang menemukan bahwa komunikasi matematika siswa belum mencapai hasil yang baik karena soal yang terlalu sulit. Ini dikarenakan siswa biasa diberikan soal-soal rutin yang umumnya terpaku pada textbook (Tandilling, 2012:25) sehingga terasa sulit mengerjakan soal-soal non-rutin. 
Hasil memuaskan yang diperoleh siswa pada kriteria penafsiran soal dan model matematika diduga karena siswa telah berlatih, tak hanya dalam diskusi selama proses pembelajaran tetapi juga dari hasil mencari sendiri melalui tugas paper disamping soal yang disajikan juga menggunakan bahasa yang mudah dipahami oleh siswa. Tugas paper yang diberikan memuat tugas mencari soal-soal yang berhubungan dengan aplikasi turunan dalam kehidupan nyata, memahaminya dan menemukan solusi penyelesaiannya. Ini terbukti membuat pembelajaran siswa lebih bermakna. Sama halnya dengan pernyataan Mandernach (2003), bahwa performance assessment task mampu mengembangkan pembelajaran bermakna bagi siswa. Akbibatnya, siswa lebih mudah dalam memahami soal dalam tes tertulis serta membuat model dari suatu permasalahan. Hal yang sama juga diperoleh pada penelitian Rasiman (2013:190), siswa dapat menyebutkan apa yang diketahui, apa yang ditanya dan juga pokok permasalahan. Penelitian Nugroho (2012:89) juga menghasilkan kemampuan siswa dalam mengubah bentuk uraian menjadi model matematika dalam kategori sedang setelah dilatih terlebih dahulu melalui diskusi dalam pembelajaran. Setelah berlatih menjawab soal ketika diskusi, Rofiah (2010:97) juga menemukan hampir setengah dari jumlah siswa mengalami peningkatan pada aspek kemampuan mengubah bentuk uraian ke dalam model matematika. Didukung pula dengan respon siswa yang menyatakan bahwa tingkat kemampuan dan kemudahan mereka dalam membuat model matematika lebih tinggi dibandingkan respon terhadap kemampuan menentukan langkah penyelesaian soal.

Berdasarkan paper yang dikerjakan siswa, hanya ada satu kelompok yang baik dalam menyatakan gambar aplikasi matematika sedangkan yang lain masih berada dalam kategori kurang sehingga rataan yang diperoleh pada kriteria ini berada dalam kategori cukup. Hal ini diasumsikan siswa SMA tidak terbiasa memanfaatkan gambar untuk mempermudah penyampaian ide matematika mereka. Padahal, beberapa persoalan sangat membutuhkan gambar untuk menyelesaikannya. Hasil yang berbeda terdapat pada studi Hamidah (2013:51) dimana 87,8\% siswa sudah menyatakan gambar melalui penerapan performance assessment.

Dari data di atas terlihat bahwa kemampuan siswa menentukan turunan fungsi aljabar sudah memuaskan dikarenakan siswa sedang menggunakan aturan turunan aljabar sederhana pada mata pelajaran fisika, sehingga mereka sudah sangat baik dalam menentukan turunan bentuk aljabar sederhana. Namun, pada soal nomor empat kebanyakan siswa tidak bisa menentukan turunan fungsi aljabar dalam bentuk pecahan secara tepat yang diduga karena turunan aljabar dalam bentuk pecahan belum pernah mereka dapatkan, kecuali pada pertemuan pertama dari pembelajaran yang dilakukan pada penelitian ini. 
Secara keseluruhan, siswa menyatakan bahwa mereka merasa lebih mampu dan lebih mudah dalam menentukan turunan fungsi aljabar dibandingkan membuat model matematika.

Kemampuan komunikasi lisan melalui presentasi menunjukkan kemampuan dalam menjawab pertanyaan mencapai kategori sangat baik dan kemampuan menyampaikan informasi, memahami makalah dan kerjasama mencapai kategori baik. Sangat baiknya kemampuan menjawab pertanyaan dikarenakan siswa sudah paham mengenai makalah dan persoalan yang ada pada makalah mereka sehingga ketika menjawab pertanyaan atau diminta mejelaskan kembali, siswa dapat menjelaskannya dengan baik. Selain itu, kerjasama yang baik juga mendukung keberhasilan suatu kelompok. Dengan demikian, tugas presentasi yang diberikan mampu membangun kerja sama yang baik antar sesama siswa dalam kelompoknya, saling menguatkan dan mengisi kekurangan dalam presentasi. Disamping itu, presentasi juga memberikan kesempatan kepada siswa untuk melatih kemampuannya dalam menjelaskan apa yang sudah mereka ketahui termasuk langkah-langkah penyelesaian soal. Rudner \& Boston serta Wiggins (Houghton Mifflin University, 1997) dan Mueller (2012) mengemukakan bahwa performance assessment memberikan siswa kesempatan untuk mendemonstrasikan pengetahuan dan strategi yang telah mereka pelajari. Jadi, presentasi tugas matematika berguna untuk mengetahui apa yang diketahui siswa (Mustamin, 2010:39) serta dapat menilai juga mengembangkan kemampuan komunikasi matematika siswa secara lisan. Selain itu, Mandernach (2003) juga mengatakan, penilaian ini dapat membangun kerjasama di kalangan siswa.

Dari analisis angket ditemukan respon siswa mengenai barunya komponen pembelajaran lebih dari setengah persen. Kesenangan mereka terhadap komponen pembelajaran tersebut juga menunjukkan respon postif. Siswa menyatakan berminat mengikuti pembelajaran dengan penerapan performance assessment. Ini menjawab rumusan masalah yang kedua mengenai respon siswa terhadap pembelajaran. Hal ini diduga karena siswa jarang diterapkan diskusi, tugas paper dan presentasi dalam pembelajaran matematika, sehingga dapat membuat mereka antusias dalam mengikuti pembelajaran. Selain itu, penerapan tugas yang bervariasi juga membuat siswa tidak merasa bosan. Arends (2004:246) mengatakan, performance assessment task memungkinkan siswa dinilai dari tugas yang bervariasi. Kemudian, respon yang sama juga diperoleh pada studi Hamidah (2013:64) yang mengatakan bahwa siswa berminat mengikuti pembelajaran dengan penerapan performance assessment.

Dapat kita disimpulkan bahwa, rata-rata tertinggi melalui tugas paper terdapat pada kemampuan menyatakan model matematika, proses aljabar dan 
perhitungan serta penafsiran terhadap soal yaitu berada dalam kategori sangat baik, sedangkan yang terendah adalah menyatakan ide/situasi melalui gambar dengan kategori cukup. Sementara melalui presentasi, kemampuan yang tertinggi adalah menjawab pertanyaan dengan kategori sangat baik dan terendah adalah kerjasama dengan kategori baik. Terakhir melalui tes tertulis, kemampuan tertinggi adalah proses aljabar/perhitungan berada dalam kategori baik dan terendah adalah menyatakan kesimpulan berada dalam kategori cukup. Sementara respon siswa terhadap penerapan performance assessment umumnya positif.

\section{DAFTAR PUSTAKA}

Agustyaningrum, Nina. 2010. Implementasi Model Pembelajaran Learning Cycle $5 E$ Untuk Meningkatkan Kemampuan Komunikasi Matematis Siswa Kelas IX B SMP Negeri 2 Sleman. Skripsi. Yogyakarta: Universitas Negeri Yogyakarta.

Airasian, Peter W. 2005. Classroom Assessment: Concepts and Applications $\left(5^{\text {th }} e d.\right)$. New York: McGraw Hill.

Allen, Russ. 2013. Performance Assessment. Winconsin Education Association (WEAC),(http://www.weac.org/Professional Resources/Testing/perform ance assessment.aspx, diakses 27 Februari 2014).

Arends, Richard I. 2004. Learning to Teach (6th ed.). NewYork: McGraw Hill. Arikunto, Suharsimi. 2010. Prosedur Penelitian Sebagai Suatu Pendekatan Praktek. Jakarta: Rineka Cipta.

Brualdi, Amy C. 1998. Implementing Performance Assessment in the Classroom. Practical Assessment, Research \& Evaluation, 6(2), (http://PAREonline.net/getvn.asp?v=6\&n=2, diakses 27 Februari 2014).

Bungin, Burhan M. 2009. Metodologi Penelitian Kuantitatif: Komunikasi, Ekonomi dan Kebijakan. Jakarta: Kencana.

CSSU Curriculum Frameworks. 2004. Math Frameworks, (http://www. cssu.org/cms/lib5/VT01000775/Centricity/Domain/32/CSSUMathCurric May04.pdf, diakses 27 Februari 2014).

Edutopia. 2008. "What are Some Types of Assessment? There are many alternatives to traditional standardized tests that offer a variety of ways to measure student understanding", July 2008. (http://www. edutopia.org/assessment-guide-description, diakses 5 Maret 2013).

Fachrurazi. 2011. Penerapan Pembelajaran Berbasis masalah untuk Meningkatkan Kemampuan Berpikir Kritis dan Komunikasi Matematis Siswa Sekolah Dasar. Jurnal UPI, Edisi khusus, (1):76-89.

Hajjina, Cut Yuni Nurul. 2013. Kemampuan Komunikasi Siswa melalui Problem Based Learning di Kelas XI SMA Teuku Nyak Arif Fatih 
Bilingual School Banda Aceh. Skripsi. Banda Aceh: FKIP Universitas Syiah Kuala.

Houghton Mifflin University. 1997. What is Authentic Assessment?, (http://www.eduplace.com/rdg/res/litass/auth.html, diakses 5 Maret 2013).

Idha, Cheiriyah. 2008. Meningkatkan Pemahaman Konsep Mata Pelajaran Biologi melalui Performance Assessment. Jurnal Pendidikan Inovatif, 3(2): 69-73.

Kavlu, Sukru dan Aydin Saglam. 2005. Derivatives. Turki: Zambak Publishing.

Kementerian Pendidikan dan Kebudayaan. 2013. Pembelajaran Berbasis Kompetensi Mata Pelajaran Matematika (Peminatan) melalui Pendekatan Saintifik, Sekolah Menengah Atas. Banda Aceh.

---------. 2013. Model Penilaian Hasil Belajar Peserta Didik Sekolah Menengah Atas. Banda Aceh.

Lane, S. 2010. Performance Assessment: The State of the Art. SCOPE Student Performance Assessment Series. Stanford, CA: Stanford University, Stanford Center for Opportunity Policy in Education.

Mahmudi, Ali. 2006. Pengembangan Kemampuan Komunikasi Matematika Siswa melalui Pembelajaran Matematika. SEMNAS Matematika dan Pendidikan Matematika, (10): 175-182.

--------. 2009. Komunikasi dalam Pembelajaran Matematika. Jurnal MIPMIPA UNHALU, 8(1): 1-9.

Mandernach, B. J. 2003. Incorporating Authentic Assessment, (Park University Faculty Development Quick Tips: http://www.park.edu/cetl/quicktips lauthassess.html, diakses 5 Maret 2013).

Meisels, Samuel J. 2013. Performance Assessment, (Error! Hyperlink reference not valid., diakses 5 Maret 2013).

Moskal, Barbara M. 2003. Recommendations for Developing Classroom Performance Assessments and Scoring Rubrics. Practical Assessment, Research \& Evaluation, 8(14), (http://PAREonline.net/getvn.asp?v $=8 \& n=14$, diakses 27 Februari 2014).

Mueller, John. 2012. Authentic Assessment Toolbox: What is Authentic Assessment?, (http://jfmueller.faculty.noctrl.edu/toolbox/, diakses 27 Februari 2014).

Mustamin, Hasmiah St., Meningkatkan Hasil Belajar Matematika melalui Penerapan Asesmen kinerja. Jurnal Lentera Pendidikan, 13(1): 33-43.

National Council of Teachers of Mathematics (NCTM). 2000. Principles and Standards for School Mathematics. Universitas Michigan. 
Oakland Community College. 2008. OCC Assessment Definition. Bloomfield Hills, (http://www.oaklandcc.edu/assessment/Definition.htm, diakses 5 Maret 2013)

Oermann, M. H., \& Gaberson, K. B. 2006. Evaluation and Testing in Nursing Education (2nd Ed.). New York: Springer Publishing Company.

Palm, Torulf. 2008. Performance Assessment and Authentic Assessment: A Conceptual Analysis of the Literarure. Practical Assessment, Research \& Evaluation, 13(4): 1-11.

Putri, Ratu Ilma Indra. 2011. Improving Mathematics Comunication Ability of Students in Grade 2 through PMRI Approach. International Seminar and the Fourth National Conference on Mathematics Education 2011, Juli 2011:547-556.

Qohar, Abd. 2009. Penggunaan Reciprocal Teaching untuk Mengembangkan Komunikasi Matematis. Prosiding Seminar National penelitian, Pendidikan dan Penerapan MIPA, Mei 2009: M-337-M-342.

Sa'dijah, Cholis. 2009. Asesmen Kinerja dalam Pembelajaran Matematika. Jurnal Pendidikan Inovatif, 4(2): 92-95.

Suci Maulina. 2014. Penerapan Performance Assesment Untuk Penilaian Kemampuan Komunikasi Matematika Siswa Kelas XI SMA Negeri 2 Banda Aceh. Universitas Syiah Kuala.

Sudjana, Nana dan Ibrahim. 2001. Penelitian dan Penilaian Pendidikan.

Bandung: Sinar Baru.

Sumarmo, Utari. 2006. Pembelajaran Keterampilan Membaca Matematika pada Siswa Sekolah Menengah, (http://www.academia.edu/4609768/ Sumarmo_Pembelajaran_Keterampilan_Membaca_Matematika_pada_Si swa_Sekolah_Menengah\#, diakses 1 Maret 2014).

Suskie, Linda. 2009. Assessing Student Learning. USA: Jossey-Bass.

Umar, Wahid. 2012. Membangun Kemampuan Komunikasi Matematis dalam Pembelajaran Matematika. Jurnal Ilmiah Program Studi Matematika STKIP Siliwangi, Bandung, 1(1): 178-185.

Wren, Douglas G. 2009. Performance Assessment: A Key Component of a Balanced Assessment System. Research Brief, Research from the Department of Research, Evaluation, and Assessment, (2): 1-12. 